\title{
Os meios consensuais de resolução de conflitos como indicativos do acesso à justiça
}

\section{no estado constitucional}

\author{
The consensual means of conflict resolution as indicators of access to justice in the constitutional
}

state

\section{Los médios consensuales de resolución de conflictos como indicadores de acceso a la justicia en el estado constitucional}

\begin{abstract}
Resumo
O Estado Constitucional trouxe nova formatação à função jurisdicional, bem como a ampliação do direito fundamental de acesso à justiça. Daí se extrai o objetivo do presente artigo, qual seja, verificar a existência dos meios consensuais de resolução de conflitos como característica marcante deduzida pela concepção jurisdicional contemporânea, distanciando-se da visão tradicional de jurisdição. Com isso, o presente artigo tem por objetivo reconhecer a realidade plural no que concerne de meios de solução de conflitos, mediante o exame de adequação da via eleita pelas próprias partes, o que também é conhecido como justiça multiportas, ante a presença de técnicas como a conciliação, a mediação e até mesmo a arbitragem, apesar da proximidade existente dessa última com a natureza jurisdicional. Dessa forma, por meio de revisão de bibliografia especializada, infere-se que o pretenso fortalecimento do Poder Judiciário também indica a abertura processual a métodos de solução de controvérsias baseados na consensualidade, em vista da agilidade proporcionada por tais meios, assim como a maior probabilidade de satisfação social obtida a partir de uma espécie de autogestão dos conflitos amparada substancialmente no primado da autonomia da vontade.
\end{abstract}

Palavras-chave: Estado constitucional; Função jurisdicional; Solução de conflitos; Conciliação; Mediação.

\begin{abstract}
The Constitutional State brought a new format to the jurisdictional function, as well as the expansion of the fundamental right of access to justice. Hence, the objective of this article is extracted, namely, to verify the existence of consensual means of conflict resolution as a striking feature deduced by the contemporary jurisdictional conception, distancing itself from the traditional view of jurisdiction. Thus, this article aims to recognize the plural reality with regard to means of conflict resolution, by examining the adequacy of the path chosen by the parties themselves, which is also known as multi-door justice, given the presence of techniques such as conciliation, mediation and even arbitration, despite the proximity of the latter with the jurisdictional nature. Thus, through a review of specialized bibliography, it is inferred that the alleged strengthening of the Judiciary also indicates the procedural opening to dispute settlement methods based on consensuality, in view of the agility provided by such means, as well as the greater probability of social satisfaction obtained from a kind of self-management of conflicts substantially supported by the primacy of the autonomy of the will.
\end{abstract}

Keywords: Constitutional state; Jurisdictional function; Conflict resolution; Conciliation; Mediation.

\section{Resumen}

El Estado Constitucional aportó un nuevo formato a la función jurisdiccional, así como la ampliación del derecho fundamental de acceso a la justicia. De ahí que se extraiga el objetivo de este artículo, a saber, verificar la existencia de medios consensuales de resolución de conflictos como una característica llamativa deducida por la concepción jurisdiccional contemporánea, distanciándose de la visión tradicional de jurisdicción. Así, este artículo pretende reconocer la realidad plural en cuanto a los medios de resolución de conflictos, examinando la adecuación del camino elegido por las propias partes, lo que también se conoce como justicia multiportada, dada la presencia de técnicas como la conciliación, la mediación e incluso el arbitraje, a pesar de la proximidad de este último con el carácter 
jurisdiccional. Así, a través de una revisión de bibliografía especializada, se infiere que el supuesto fortalecimiento del Poder Judicial también indica la apertura procesal a los métodos de solución de controversias basados en la consensualidad, en vista de la agilidad que proporcionan tales medios, así como la mayor probabilidad de satisfacción social obtenida de una especie de autogestión de conflictos sustancialmente apoyada en la primacía de la autonomía de la voluntad.

Palabras clave: Estado constitucional; Función jurisdiccional; Resolución de conflictos; Conciliación; Mediación.

\section{Introdução}

Tal como qualquer outra sociedade dinâmica, natural e inevitavelmente sujeita a avanços e atritos sociais, a sociedade brasileira não é exceção no que concerne à existência patente de conflitos de diversas naturezas e origens. Por essa razão, há um ordenamento jurídico de direito material, atribuindo a titularidade de direitos e assentando relações jurídicas, e de direito processual, destinado a reger os procedimentos judiciais ante os casos de controvérsias, situações em que os interesses de partes distintas colidem e, dessa forma, dão origem a pretensões resistidas e insatisfeitas.

A Constituição Federal, sem dúvidas, assentou a estrutura de um Estado Democrático de Direito, no qual se encerra as noções substanciais da legalidade e da separação das funções estatais. Sendo assim, arregimentado na legalidade validade pelos vetores constitucionais, a função jurisdicional, desempenhada preponderantemente pelo Poder Judiciário, exerce importante tarefa na resolução de conflitos de interesses, prestando a tutela jurisdicional com a estabilidade marcante da coisa julgada, o que confere segurança jurídica no sentido da previsibilidade sentida pelo corpo social.

Todavia, impera a realidade da não integral satisfação social com a estrutura burocrática do aparato tradicional de jurisdição, a despeito do direito fundamental de acesso à justiça constitucionalmente assegurado. A propósito, entende-se o advento do Estado Constitucional como uma via ampliativa de acesso aos mecanismos solucionadores de litígios, a ponto de o próprio ente estatal permitir à sociedade a possibilidade de se efetuar uma espécie de autogestão dos conflitos privados, razão pela qual a estrutura processual contemporânea traz, em seu arranjo de regras, a abertura para a acessibilidade social à conciliação, à mediação e à arbitragem, embora, quanto à última, reconheça-se a proximidade com a atividade tipicamente jurisdicional.

Portanto, tem o presente artigo o objetivo de demonstrar uma noção do denominado Estado Constitucional, particularmente no que toca à função jurisdicional, de maneira a entender o processo de constitucionalização do direito como o fortalecimento dos enunciados fundamentais, dentre eles, o direito de acesso à justiça, aqui compreendido de forma ampliada, abarcando, com isso, a análise de adequação dos meios resolutivos de contendas a partir do sistema justiça multiportas, compreendido, aqui, como a possibilidade de as partes ligantes submeterem suas contendas pessoais à via consensual e/ou ao crivo do juízo arbitral, ambos regimentados sob o primado da autonomia da vontade.

\section{Metodologia}

O presente artigo se fundamenta em estudo teórico de natureza essencialmente bibliográfica, por meio do qual se busca conhecer os precedentes histórico-jurídicos do chamado Estado Constitucional. Para tanto, nas palavras de Cervo (2007, p. 60-61), considerar-se-á a metodologia da pesquisa bibliográfica como ferramenta descritiva indispensável ao se "explicar um problema a partir de referências teóricas publicadas em artigos, livros, dissertações e teses", particularmente quando se pretende "conhecer e analisar as contribuições culturais ou científicas do passado sobre determinado assunto, tema ou problema", uma vez que tal método "constitui a pesquisa propriamente dita na área das ciências humanas".

De início, parte-se da noção de Estado Legislativo, em que a função jurisdicional exercia meramente o papel de reprodução estanque dos textos normativos, positivados como representação da vontade do legislador da época. Posteriormente, registra-se que, com a necessidade de limitação do poder totalitário, baseado puramente no arbítrio ostentado 
pela pessoa do soberano, passou-se a subscrever a proposta de demarcações constitucionais aos poderes e medidas de preservação de direitos fundamentais - a princípio, os direitos individuais (liberdade e propriedade), com preponderância.

Com amparo em bibliografia especializada, lastreada em livros e artigos científicos, evidencia-se a fase da jurisdição exercida na ambiência marcada pelo advento do Estado Constitucional, também chamado contemporaneamente de Estado Democrático de Direito, momento a partir do qual se opera a judicialização dos conflitos sociais. Nesse contexto, destaca-se o acesso à justiça sob uma ótica mais abrangente, transcendendo a ideia limitada de resolução de contendas coletivas tão somente por meio do aparato burocrático do Poder Judiciário, com uma decisão judicial, transitada em julgado e marcada pela imutabilidade de uma solução proferida por terceiro imparcial, que, por vezes, não agrada qualquer das partes envolvidas na situação conflituosa da vida.

Demais disso, apresenta-se os meios consensuais de resolução de conflitos como uma percepção ampliada do conceito de acesso à justiça, na medida em que as próprias partes possuem a alternativa de buscarem uma solução mais próxima dos interesses de cada qual, razão por que há maior probabilidade de a solução da contenda satisfazer mais os particulares do que o pronunciamento do Estado, ao se pronunciar oficialmente e impor sua vontade soberana e modular à prática de interesses privados.

Dessa forma, por intermédio de autores processualistas nacionais, após uma necessária apresentação conceitual, analisa-se, com brevidade, a sistemática da mediação, da conciliação e da arbitragem, bem como se explana a respeito do incentivo estatal sobre a implementação gradual dos mecanismos consensuais de resolução de conflitos sociais, até mesmo como uma forma de agilizar a dinâmica jurídica e social ante a sobrecarga de trabalho atualmente evidenciada no âmbito do Poder Judiciário, notadamente em face da crença ainda existente de que somente o Estado é capaz de materializar os preceitos de justiça por seu proceder jurisdicional.

Por derradeiro, o presente artigo oferece importante contribuição científica, mormente pelo potencial de integrar o arranjo de material bibliográfico relacionado à temática em comento, tendo em conta que, conforme apregoa Gil (2002, p. 44), "A pesquisa bibliográfica é desenvolvida com base em material já elaborado, constituído principalmente de livros e artigos científicos", não se podendo olvidar que "há pesquisas científicas desenvolvidas exclusivamente a partir de fontes bibliográficas".

\section{Resultados e Discussão}

\subsection{A jurisdição frente ao Estado Constitucional}

Antes de tudo, para se chegar ao momento histórico em que o Estado assume sua função jurisdicional abalizado por toda uma conjuntura de proteção de direitos fundamentais, igualmente previstos no bojo de uma Constituição rígida, orientados à salvaguarda tanto da liberdade individual como dos direitos de natureza social, atentos às desigualdades econômicas entranhadas na estrutura das sociedades, torna-se imperiosa a descrição, ainda que sucinta, do tratamento histórico-jurídico relativo à formatação do modelo jurisdicional aplicado durante a vigência do Estado Liberal, ou Estado Legislativo.

No contexto da queda do denominado Estado Legislativo, limitado basicamente aos enunciados normativos proclamados pelos legisladores, Mendes (2016, p. 154) afirma que "a lei bastava em si mesma, representando o norte para o ordenamento jurídico de um Estado". Segundo o autor, isso ocorria porque "a lei em sua origem, e no intuito de evitar os abusos do Regime Deposto, era vista pelo parlamento como norma genérica e abstrata, por considerar a sociedade isonômica em sua totalidade".

Partindo-se dessa concepção legal caldada em normatividade genérica e abstrata, representando o tradicional princípio da legalidade, verificaram-se "reflexos relativamente drásticos sobre a função da jurisdição", tendo em vista que "ao juiz sucedia a proibição de exercício da hermenêutica jurídica e, dessa forma, impossibilitado estava de chegar o mais próximo 
possível da utópica ideia de justiça por não interpretar a norma", atividade com a qual se torna possível considerar "as diferenças entre as pessoas em conflito e as peculiaridades do caso concreto" (Mendes, 2016, p. 159).

Essa tendência de compreensão legislativa, que, praticamente, considerava a pura letra da lei como a enunciação máxima do universo jurídico-conceitual a reger a vida individual e coletiva, "até a Segunda Guerra Mundial, prevalecia no velho continente", incorporando "a cultura de que a lei editada pelo legislativo era fonte principal, quase exclusiva, de Direito. O juiz era a 'boca' da lei, como se referia Montesquieu". Inclusive, "As Constituições eram vistas como programa político que serviam para inspirar a atuação legiferante, mas não podiam ser invocadas perante o Poder Judiciário para defesa de direitos" (Padilha, 2020, p. 47).

Nessa toada, acentua Mendes (2016), somente a partir do reconhecimento da existência de uma sociedade atormentada pelas desigualdades, iniciou-se a gradual materialização do chamado Estado Constitucional, e, com ele, germinou a ideia de uma sociedade e um Estado amparado por um documento superior. Assim sendo, "desencadeou-se intensa movimentação político-social no sentido de elevar um documento normativo à classe de legislação fundamental”, devendo referido documento ser "guarnecido de um dever objetivo de observância e adequação quanto aos seus termos, pelo legislador ordinário, quando do exercício da atividade legislativa" (Mendes, 2016, p. 154).

Mendes (2016, p. 161) também realça que, a partir do advento do Estado Constitucional de Direito e do princípio da legalidade em sua formatação substancial, a qual observa a realidade social tal como ela de fato o é, ou seja, economicamente desigual, o fenômeno da Jurisdição, enfim, "ganhou uma 'roupagem', deixando de simplesmente expor e aplicar o texto da lei, para materializar, no Estado-juiz, a posição de intérprete desta mesma lei, a qual deve estar conforme a Constituição", de modo que se abre espaço para a adoção do "princípio da supremacia da Constituição, com a qual a lei tem o dever objetivo de conformar-se, observando o juiz, no exercício de sua atividade, os direitos fundamentais e princípios de justiça".

Dessa forma, o citado autor consigna que, "Na configuração do Estado Contemporâneo, os princípios constitucionais e os direitos fundamentais assumem basilar importância em razão do sentido e da validade que conferem à lei, no curso da atividade interpretativa do juiz", de modo que "o julgador faça a compreensão da lei de acordo com o caso concreto, e que as peculiaridades sejam levadas em consideração quando da sentença, que porá fim à questão e satisfará a prestação jurisdicional" (Mendes, 2016, p. 162).

Percebe-se, pois, que a função jurisdicional há de ser alicerçada pelos mandamentos inscritos no corpo do Texto Constitucional, em que também se encontram os princípios fundamentais, indicadores basilares da atuação do juiz quando da aplicação do lei ao caso concreto, a partir de sua atividade essencialmente interpretativa, por meio da qual busca amoldar a situação fática lhe apresentada ao fundamento jurídico correspondente no ordenamento jurídico, na medida em que guarda relação de compatibilidade com as diretrizes importas pela Lei Magna.

Por essas razões, no Estado Jurisdicional Contemporâneo, como base fundante da regência do Estado e da vida social, a noção apresentada pela existência de uma Constituição atualmente transcende aquela tradicional acepção de constitucionalismo tão somente como mecanismo de limitação objetiva de poder, particularmente do poder despótico e intrinsecamente autoritário. Desse modo, "o mero constitucionalismo, que buscava limitação do poder político, já não é mais suficiente; mais do que limitação, é necessário garantir a eficácia do texto magno” (Padilha, 2020, p. 48).

Em tempos recentes, portanto, como se observa a partir da extensa produção doutrinária nacional, fala-se no nascimento e na pretensa obediência ao denominado neoconstitucionalismo, que possui, como duas de suas características marcantes, a constitucionalização do direito, consistente, em última análise, na "onipresença da Constituição, ou seja, a irradiação das normas e valores constitucionais para todos os ramos do direito", ao lado do fenômeno da judicialização, fruto, dentre outros fatores, da "redemocratização do país, que por meio da Carta de 1988, fortaleceu e expandiu o Poder Judiciário, o 
Ministério Público e a Defensoria Pública, bem como aumentou a demanda por justiça na sociedade brasileira" (Padilha, 2020, p. 49).

\subsection{Acesso à justiça no Estado Constitucional brasileiro}

A sociedade, então, com o fortalecimento e a expansão de órgãos do Estado, destinados a solucionar conflitos de interesses de variadas ordens, credita especialmente ao Poder Judiciário a missão de protetor social e dirimente de todas as contendas suscitadas pelas circunstâncias adversas do convívio coletivo. E, da crença de que a resposta estritamente judiciária seja a mais confiante via de obtenção da pacificação social, dificilmente os jurisdicionados, potenciais e/ou efetivos, conseguem perceber que o próprio Estado assegura à sociedade outras plataformas de resolução de litígios, não raramente menos morosos e com maior presteza na atividade de restabelecimento da harmonia na ordem privada.

Essa crença social também encontra sua razão de ser na previsão constitucional da inafastabilidade da jurisdição, salvaguardando-se, dessa maneira, o amplo acesso ao sistema de justiça brasileiro. Para tanto, a Constituição Federal/1988 anuncia que "a lei não excluirá da apreciação do Poder Judiciário lesão ou ameaça a direito" (art. $5^{\circ}$, XXXV). Essa diretriz fora reproduzida pelo Código de Processo Civil (CPC), em seu art. $3^{\circ}$, que assim dispõe: "Não se excluirá da apreciação jurisdicional lesão ou ameaça a direito".

Assim, segundo Medina (2020, p. 43), “Ao referir-se tanto à lesão quanto à ameaça, deixa claro a Constituição que a jurisdição deve realizar o Direito, restaurando a ordem jurídica violada ou evitando que tal violação ocorra, através de procedimento ordenado para esse fim". Isto é, para o autor, "pode-se dizer que o princípio constitucional revela que não se concebe que a atividade jurisdicional seja entendida como 'agir orientado pelo passado', mas 'orientada por normas fundamentais', deve a jurisdição voltar-se a 'problemas do presente e do futuro"”.

Dito isso, Medina (2020) faz expressa menção à Resolução nº 125/2010, do Conselho Nacional de Justiça (CNJ), para embasar a existência de uma justiça multiportas existente na esfera do sistema de justiça pátrio. Por isso, como justificação desse mecanismo alternativo, a citada resolução considera que "a eficiência operacional, o acesso ao sistema de justiça e a responsabilidade social são objetivos estratégicos do Poder Judiciário", e "o direito de acesso à justiça, previsto no art. $5^{\circ}$, XXXV, da Constituição Federal, além de vertente formal perante os órgãos judiciários, implica acesso à ordem jurídica justa e a soluções efetivas" (Brasil, 2010).

Para a efetivação desse sistema, conforme o teor da própria Resolução no 125/2010, o CNJ esclarece que "cabe ao Judiciário estabelecer política pública de tratamento adequado dos problemas jurídicos e dos conflitos de interesses”, haja vista "que ocorrem em larga e crescente escala na sociedade, de forma a organizar, em âmbito nacional, não somente os serviços prestados nos processos judiciais", além dos "que possam sê-lo mediante outros mecanismos de solução de conflitos, em especial dos consensuais, como a mediação e a conciliação", reconhecendo-se, pois, "a necessidade de se consolidar uma política pública permanente de incentivo e aperfeiçoamento dos mecanismos consensuais de solução de litígios” (Brasil, 2010).

Medina (2020) expõe que esse raciocínio fora incorporado pelo atual CPC, em razão de o referido diploma processual permitir a realização da arbitragem, na forma da lei $\left(\operatorname{art.} 3^{\circ}, \S 1^{\circ}\right)$, bem como ao proclamar que "Estado promoverá, sempre que possível, a solução consensual dos conflitos" (art. $3^{\circ}, \S 2^{\circ}$ ). Além disso, o Código processual é mais direto sobre a atuação esperada do Estado e de seu respectivo sistema judiciário quando prega que "A conciliação, a mediação e outros métodos de solução consensual de conflitos deverão ser estimulados por juízes, advogados, defensores públicos e membros do Ministério Público", a ponto de tal estímulo ser efetuado no curso do processo judicial, inclusive (art. $3^{\circ}, \S 3^{\circ}$ ).

O CPC, inclusive, ao tratar sobre os conciliadores e mediadores judiciais, estabelece que "Os tribunais criarão centros judiciários de solução consensual de conflitos, responsáveis pela realização de sessões e audiências de conciliação e mediação e pelo desenvolvimento de programas destinados a auxiliar, orientar e estimular a autocomposição" (art. 165); considerando-se 
que "A composição e a organização dos centros serão definidas pelo respectivo tribunal, observadas as normas do Conselho Nacional de Justiça” (§ $\left.1^{\circ}\right)$.

Ante o exposto, deve-se reconhecer que o Estado brasileiro, especialmente quando representado pela atuação dos seus órgãos jurisdicionais, não se desvencilha da tarefa imprescindível de solucionar os conflitos de interesse existente no seu agrupamento social. Pelo contrário, em sua dimensão jurídica contemporânea e constitucionalizada, o Poder Público propala a constitucionalização do direito de todo cidadão ter sua causa apreciada em sede jurisdicional, obtendo, assim, uma resposta do Poder Judiciário a respeito do caso concreto levado oportuna e tempestivamente à apreciação estatal.

Todavia, o compromisso estatal com a pacificação social transcende a mera limitação da engrenagem judiciária tradicional, a ponto de assumir a missão de oferecer à sociedade outros mecanismos capazes de resolver litígios, conquanto limitado à atuação alternativa de natureza cível, especialmente no que concerne a direitos disponíveis, como será tratado mais adiante. De qualquer forma, tem-se a ampliação das possibilidades de resolução de contendas sociais, o que, por inevitável, agiliza a estrutura institucional e concentra esforços num campo não tão sobrecarregado de processos judiciais, evitando-se, também, a duração excessiva de procedimentos sem a efetiva prestação da esperada tutela do direito alegadamente violado.

A despeito disso, conforme alerta Medina (2020, p. 44), no âmbito da processualística civil, "não basta, porém, conceber meios alternativos à jurisdição ordinária para a solução de conflitos ou, pior ainda, simplesmente impô-los aos litigantes". Para além disso, segundo o autor, torna-se "necessário compreender a natureza do conflito para verificar qual o meio mais adequado para solucioná-lo". A propósito, não se pode esquecer que "A necessidade de adequação da tutela de direitos não se dá apenas na forma judiciária" (Marinoni, Arenhart \& Mitidiero, 2017, p. 158).

Depreende-se, pois, que, para realmente compreender a extensão processual e constitucional do Estado contemporâneo, no que toca ao acesso popular aos mecanismos solucionadores de controvérsias sociais como formas de acesso à justiça, imprescindível é analisar como um desses mecanismos, quais seja, a conciliação, a mediação e a arbitragem, a fim de elucidar a razão de ser de cada um desses novos sistemas de pretensa pacificação social, vez que "o acesso à justiça é direito social básico do cidadão. Contudo esse direito não está restrito ao mero acesso aos órgãos judiciais e ao aparelho judiciário estatal. Muito além disso, deve representar um efetivo acesso à ordem jurídica justa" (Pinho, 2020, p. 64).

\subsection{Dos meios consensuais de solução de conflitos}

Antes mesmo de abordar quaisquer das metodologias processuais destinadas à solução de conflitos, cabe entender, de fato, o que se quer representar com esta expressão tão arraigada pelas doutrinas processualistas, a saber, o conflito. De qualquer forma, depreende-se que, "Apesar dos esforços envidados pelo legislador em conferir maior eficácia aos processos jurisdicionais, a verdade é que o Estado tem encontrado dificuldades em solucionar, de forma célere, eficaz e adequada, os conflitos a ele submetidos" (Rodrigues, 2018, p. 365).

Para Tartuce (2019), antes de tudo, o conflito deve ser encarado como uma crise na interação humana. A partir disso, torna-se possível identificá-lo por meio de expressões sinônimas, tais como, embate, oposição, pendência, pleito; uma vez que, na linguagem técnico-jurídica, referido termo comumente remete à ideia de colisão de interesses, em razão do qual se inaugura uma divergência entre pessoas, fatos e/ou coisas.

Tartuce (2019) também ensina que, uma vez que o Estado pretenda solucionar conflitos de interesses, parte-se do pressuposto que, em tal situação, há evidente circunstância de tensão, sendo que a perspectiva jurídica é direcionada a enfrentála, para satisfazer os interesses postos em discussão. Porém, essa tarefa de satisfazer alguém é muito mais complexa do que simplesmente apresentar uma das respostas contidas no ordenamento jurídico, principalmente ante uma sociedade convulsionada e hiperdinâmica, profundamente marcada por controvérsias. 
Por isso que, "No acesso à justiça no modelo tradicional, a busca da solução final acaba se resumindo a resolver apenas a crise jurídica, deixando em aberto os impasses de outras naturezas", que, não raramente, também "não costumam ser conjuntamente dirimidos" (Tartuce, 2019, p. 14). Trata-se, no caso, da não satisfação integral dos interesses conflitantes deduzidos pelas partes no curso da relação processual na via judiciária tradicional, que, em tese, substituindo essas partes quando da prolação da decisão judicial, pode, por vezes, deixar uma lacuna em relação a aspectos outros, ainda que diretamente relacionados com os fatos, mas não totalmente apreciados pela burocracia judicial.

Por conseguinte, nesse ambiente de procura por meios efetivamente sanadores de controvérsias sociais, a conciliação e a mediação ganham especial relevância, mormente ao emergirem no cenário prático-jurídico como instrumentos de composição de litígios, notadamente pela tendência atual da autocomposição, consistente na possibilidade por meio da qual "as partes resolvam, isoladamente ou em conjunto, uma saída para o conflito", oportunidade em que "a composição do conflito contará com a vontade de uma ou ambas as partes para que se verifique, inexistindo a participação de um terceiro com poder decisório para definir o impasse" (Tartuce, 2019, p. 15).

Nessa toada, Monnerat (2020) leciona que, na heterocomposição, há um estranho à lide que participa da discussão voltada à resolução da controvérsia, sendo, de certo modo, um acordo de vontades entre as partes, contando, todavia, com a presença de um terceiro imparcial, estranho ao conflito, quer eleito, quer aceito pelas partes. Dessa forma, a depender do nível de interação e condução do diálogo empreendido por esse terceiro, classificar-se-á, então, o método consensual como conciliação ou mediação.

Conforme assinala Medina (2020), tanto a conciliação quanto a mediação podem ser realizadas pelas vias judicial e extrajudicial. O CPC, no entanto, a partir do art. 165, enfatiza a conciliação e a mediação judiciais, executadas por meio da participação de conciliador ou mediador na condição de auxiliares do sistema de justiça, o que, não obstante, não significa impedimento para que as partes optem por utilizar as formas extrajudiciais de conciliação e de mediação.

Observe-se que "O ato de acionar a jurisdição estatal para a solução de qualquer conflito, por qualquer motivo e o tempo todo, já não constitui mais a única e melhor prática nas profissões ocupadas pelos operadores do Direito" (Martins, Valdetaro \& Simões, 2019, p. 77-78). Ademais, no âmbito dos mecanismos de solução consensual de conflitos, assente-se que "É preciso dar voz a quem vive o conflito. Colocá-lo no centro da mesa com poder decisório. Ouvi-lo com todos os sentidos. Fazê-lo acreditar que sua história não é apenas mais uma demanda" (Awad, 2018, p. 65).

Cabe, então, a análise mais detida de cada uma dessas formas de solução consensual de conflitos, na esteira do raciocínio de que tais mecanismos são meios complementares de resolução das controvérsias sociais, de modo a serem percebidos como ampliadores do acesso à justiça no contexto do Estado Constitucional, responsável pela salvaguarda dos valores constitucionais e dos direitos fundamentais.

\subsection{Notas gerais sobre a conciliação e a mediação}

Em contexto dos empecilhos advindos da judicialização massiva, constata-se que, "No Brasil, o elevado número de processos judiciais que sobrecarrega o Poder Judiciário inevitavelmente contribuiu para o fomento da mediação como iniciativa pública" (Fuoco, 2015, p. 278). Há de se ressaltar, por outro lado, a título de reflexão preambular, que, "Mesmo que a mediação judicial tenha efeitos positivos e contribua para modernizar os sistemas de justiça, é modalidade mais instrumental, que se integra à cultura jurídica e à normatividade" (Ávila, 2012, p. 197).

A propósito, tem-se que "A mediação se trata de um meio consensual, ou seja, não adversarial de prevenção, condução e pacificação de conflitos, por meio do diálogo e do uso de técnicas que visam a estimular as partes a obter solução consensual". E por esse motivo se diz que "O instrumento da mediação é o diálogo conduzido por técnicas operadas pelos mediadores, os quais devem ter postura neutra e imparcial em relação às partes e ao conflito", não podendo, inclusive, "realizar 
juízo de valor acerca do caso nem, tampouco, sugerir ou impor soluções" (Rius, 2020, p. 22). Tem-se em conta, pois, que "O papel do interventor é ajudar na comunicação por meio da neutralização de emoções, formação de opiniões e negociação de acordos" (Pinho, 2015, p. 123).

Além do que, no âmbito estritamente judicial, o conciliador e o mediador "atuam, sobretudo, após o recebimento da petição inicial, por força do art. 334 do CPC, que prevê a realização da audiência de conciliação ou a sessão de mediação como etapa quase obrigatória do processo", não sendo efetuado tão somente "quando ambas as partes manifestarem desinteresse na autocomposição ou quando a causa não admiti-la” (Filho, 2018, p. 261).

Assim, partindo-se do exame das disposições processuais, o aludido art. 334, do CPC, dispõe que, "Se a petição inicial preencher os requisitos essenciais e não for o caso de improcedência liminar do pedido", o juiz, então, "designará audiência de conciliação ou de mediação com antecedência mínima de 30 (trinta) dias, devendo ser citado o réu com pelo menos 20 (vinte) dias de antecedência", sendo que "O conciliador ou mediador, onde houver, atuará necessariamente na audiência de conciliação ou de mediação" ( $\left(1^{\circ}\right)$, não havendo referida audiência somente "se ambas as partes manifestarem, expressamente, desinteresse na composição consensual" (I) ou "quando não se admitir a autocomposição" (II).

Didaticamente, o CPC também define o âmbito de atuação de cada um desses profissionais da resolução consensual dos conflitos, na medida em que prescreve, de início, que o conciliador "atuará preferencialmente nos casos em que não houver vínculo anterior entre as partes, poderá sugerir soluções para o litígio, sendo vedada a utilização de qualquer tipo de constrangimento ou intimidação para que as partes conciliem" (art. 165, § $2^{\circ}$ ).

Já no que toca ao mediador, o diploma processual também é claro ao dispor que esse profissional "atuará preferencialmente nos casos em que houver vínculo anterior entre as partes", bem como "auxiliará aos interessados a compreender as questões e os interesses em conflito, de modo que eles possam, pelo restabelecimento da comunicação, identificar, por si próprios, soluções consensuais que gerem benefícios mútuos” (art. 165, § $3^{\circ}$ ).

Acerca da atuação a ser desempenhada pelos conciliadores e mediadores, o CPC determina que "A conciliação e a mediação são informadas pelos princípios da independência, da imparcialidade, da autonomia da vontade, da confidencialidade, da oralidade, da informalidade e da decisão informada" (art. 166, caput). Por oportuno, entende-se a confidencialidade como o sigilo devidamente guardado em relação "a todas as informações produzidas no curso do procedimento, cujo teor não poderá ser utilizado para fim diverso daquele previsto por expressa deliberação das partes" $\left(\S 1^{\circ}\right)$, não podendo, com isso, "divulgar ou depor acerca de fatos ou elementos oriundos da conciliação ou da mediação" $\left(\S 2^{\circ}\right)$.

Além disso, o CNJ, "a fim de assegurar o desenvolvimento da Política Pública de tratamento adequado dos conflitos e a qualidade dos serviços de conciliação e mediação enquanto instrumentos efetivos de pacificação social e de prevenção de litígios", instituiu o Código de Ética de Conciliadores e Mediadores Judiciais, que, em seu art. $1^{\circ}$, com a redação dada pela Emenda $n^{\circ}$ 2, de 8 de março de 2016, acrescenta os princípios fundamentais da competência, do respeito à ordem pública e às leis vigentes, do empoderamento e da validação, como "princípios que formam a consciência dos terceiros facilitadores, como profissionais", que "representam imperativos de conduta".

De todo modo, anote-se que tais disposições expressamente enunciadas pelo Código processual é um sinal cristalino de que "O CPC/2015 aposta na conciliação e na mediação como técnicas que podem contribuir para a solução dos conflitos de interesses em espaço de tempo menor, sobretudo no início do processo" (Filho, 2018, p. 261). Assim, no que toca à mediação, consigne-se que "Qualquer técnica de mediação pode ser utilizada para uma grande variedade de objetivos, dependendo das metas implícitas ou explícitas do mediador ao utilizá-las” (Folger, Neto \& Barros, 2016, p. 441).

Além do mais, especificamente sobre a técnica da mediação, ainda existe a Lei no 13.140, de 26 de junho de 2015, que “dispõe sobre a mediação entre particulares como meio de solução de controvérsias e sobre a autocomposição de conflitos no âmbito da administração pública" (art. $1^{\circ}$ ). Por definição legal, então, "considera-se mediação a atividade técnica exercida por 
terceiro imparcial sem poder decisório, que, escolhido ou aceito pelas partes, as auxilia e estimula a identificar ou desenvolver soluções consensuais para a controvérsia" (parágrafo único).

Importante registro da Lei de Mediação é a segundo a qual "Ninguém será obrigado a permanecer em procedimento de mediação" (art. $2^{\circ}, \S 2^{\circ}$ ), em clara observância ao princípio constitucional da legalidade em sentido amplo, vez que "ninguém será obrigado a fazer ou deixar de fazer alguma coisa senão em virtude de lei” (CF, art. $5^{\circ}$, II). Isso reafirma o fato de que a mediação se trata de uma das formas de exercício da liberdade individual, qualificadamente aplicada na busca pela solução de controvérsias, especialmente no plano privado da interação humana.

Outra substancial contribuição da referida lei é a parte em que versa sobre a natureza do direito (objeto) passível de ser submetido a essa técnica de solução de conflitos, tendo em vista que, no ambiente dos chamados meios consensuais, judiciais e extrajudiciais, insta anotar o requisito indispensável para a efetivação do término do litígio por meio da consensualidade, a saber, a disponibilidade do direito debatido, teoricamente considerado como "aquele que pode ou não ser exercido por seu titular, não havendo norma cogente a impor o cumprimento do preceito sob pena de nulidade ou anulabilidade do ato praticado com sua infringência" (Tartuce, 2019, p. 16).

Nessa esteira, assim enuncia o art. $3^{\circ}$ : "Pode ser objeto de mediação o conflito que verse sobre direitos disponíveis ou sobre direitos indisponíveis que admitam transação", podendo a mediação versar sobre todo o conflito ou somente parte dele (§ $1^{\circ}$ ). A ressalva a ser feita é no sentido de que "O consenso das partes envolvendo direitos indisponíveis, mas transigíveis, deve ser homologado em juízo, exigida a oitiva do Ministério Público" $\left(\S 2^{\circ}\right)$. Dessa maneira, nítida é a lição de que "Os direitos indisponíveis não sujeitos à transação, se é que tal nomenclatura é possível, sequer poderão ser levados à discussão numa sessão de mediação [...]” (Cintra, 2016, p. 75).

Realça-se, agora menção expressa à previsão na lei específica do procedimento de mediação, seja extrajudicial (art. 21 e ss.) ou judicial (art. 24 e ss.), a tão importante garantia da confidencialidade, a partir do que "Toda e qualquer informação relativa ao procedimento de mediação será confidencial em relação a terceiros, não podendo ser revelada sequer em processo arbitral ou judicial", exceto, pela lógica consensual, "se as partes expressamente decidirem de forma diversa ou quando for exigida por lei ou necessária para cumprimento de acordo obtido pela mediação" (art. 30). Isso, no entanto, não afasta o dever de as pessoas prestarem informações à administração tributária após o termo final da mediação $\left(\S 4^{\circ}\right)$.

Nessas hipóteses acima tratadas, não obstante a maior autonomia da vontade reconhecida por ocasião da solução de conflitos, infere-se, pois, em determinadas circunstâncias, a depender, também, da disponibilidade do direito em debate, a necessidade da presença de um terceiro, estranho ao litígio, para orientar as partes na busca de uma conclusão prática suportável para os sujeitos diretamente envolvidos na controvérsia a ser solucionada, uma vez que, numa situação de pretensões frontalmente colidentes, um estranho certamente terá a isenção suficiente para conceber nuances outras a respeito do mesmo caso concreto em discussão, afastando-se, com isso, ainda que momentaneamente, a ânsia de cada parte de ver seu pleito integralmente satisfeito, em conformidade exclusiva com suas exigências pessoais.

Perpassadas as noções fundamentais relacionadas aos mecanismos de conciliação e mediação, insta abordar algumas das questões envoltas ao processo de arbitragem, de modo a percorrer sua controvérsia relação com as características da função tipicamente jurisdicional, a ponto de se colocar em debate a feição jurisdicional da justiça arbitral, que atua lado a lado com a noção de jurisdição proveniente do poder soberano do Estado jurídica e socialmente organizado.

Por essa razão, possui extrema valia a análise do citado instituto jurídico-procedimental de resolução de controvérsias coletivas, não se podendo olvidar de que “[...] é que o advento da Lei 13.140/2015 representa um divisor de águas no tratamento adequado dos conflitos no Brasil em geral e para a mediação especificamente” (Tartuce, 2016, p. 498). Com isso, neste ponto de reflexão, é viável dizer que "O objetivo do processo não é mais a solução adjudicada, na qual ele redunda, mas a busca incessante da composição amigável da disputa, que põe em risco a desejada paz social” (Basílio, 2003, p. 318). 
Portanto, percebe-se que a solução consensual dos conflitos, em especial a mediação, é "um grande avanço e gera uma grande expectativa na celeridade processual e melhor solução dos conflitos", uma vez que "o legislador eliminou formalismos desnecessários, promovendo a economia processual, simplificando os procedimentos e eliminando os incidentes processuais, através da promoção do diálogo e da autocomposição das demandas" (Azeredo \& Moura, 2018, p. 462).

\subsection{Da arbitragem ou juízo arbitral}

A partir do magistério de Medina (2020), apesar da presença marcante de toda a estrutura estatal dirigida à prestação da tutela jurisdicional, na hipótese de se discutir direitos de natureza disponível, as partes podem decidir submeter a lide à decisão de um árbitro, tendo como premissa a ideia de que jurisdição arbitral também se enquadra na definição de instrumento de composição de controvérsias legitimamente fundamentado no primado da autonomia da vontade.

Indaga-se, então, de acordo com Alvim, Granado e Ferreira (2019), sobre a natureza jurisdicional atribuída à arbitragem, uma vez que, sendo a sentença arbitral ato privado, também se destina a dirimir eventuais controvérsias afeitas a relações contratuais de natureza patrimonial de caráter disponível. Para os citados autores, adianta-se, a justiça arbitral, em verdade, trata-se de uma espécie de jurisdição privada; porém, convém consubstanciar mais argumentos a partir da ótica legal e doutrinária, a fim de se construir uma perspectiva conjuntural a respeito dos detalhes técnicos envolvidos na discussão relacionada ao método de arbitragem.

Nesse passo, a Lei $\mathrm{n}^{\circ}$ 9.307, de 23 de setembro de 1996, em seu art. $1^{\circ}$, assim enuncia: "As pessoas capazes de contratar poderão valer-se da arbitragem para dirimir litígios relativos a direitos patrimoniais disponíveis", podendo as partes, inclusive, "escolher, livremente, as regras de direito que serão aplicadas na arbitragem, desde que não haja violação aos bons costumes e à ordem pública" ( $\operatorname{art} 2^{\circ}, \S 1^{\circ}$ ). Além disso, compete às partes, de igual modo, ao optarem por submeter a solução de seus litígios ao juízo arbitral mediante convenção de arbitragem (cláusula compromissória e compromisso arbitral), "convencionar que a arbitragem se realize com base nos princípios gerais de direito, nos usos e costumes e nas regras internacionais de comércio" $\left(\S 2^{\circ}\right)$.

Por ser igualmente fundada na autonomia da vontade individual, com o instituto da arbitragem também emerge a discussão relativa à natureza jurídica da atividade executada pelos árbitros. Para tanto, o art. 18 da citada Lei de Arbitragem assevera que "O árbitro é juiz de fato e de direito, e a sentença que proferir não fica sujeita a recurso ou a homologação pelo Poder Judiciário", ao passo que, mais a frente, o art. 31 dispõe que "A sentença arbitral produz, entre as partes e seus sucessores, os mesmos efeitos da sentença proferida pelos órgãos do Poder Judiciário e, sendo condenatória, constitui título executivo". Na mesma linha, o art. 515, VII, do CPC, arrola a sentença arbitral como título executivo judicial.

Isso posto, torna-se realmente complexa a distinção radical entre a natureza das atividades desempenhadas pela jurisdição arbitral e a jurisdição eminentemente estatal. Ante tais disposições, Medina (2020) sustenta que, para se manter a tese de que a arbitragem em si não tem qualquer natureza jurisdicional, seria necessário valer-se de um conceito de jurisdição sob uma perspectiva deveras estreita, ou, simplesmente, vinculando aquela a tão somente um dos elementos integrantes da definição da tradicional jurisdição.

Medina (2020) defende que a doutrina é praticamente unânime ao afirmar a natureza jurisdicional da arbitragem, conquanto reconheça que o juízo arbitral não substitui integralmente a atividade tradicionalmente jurisdicional, pois, apesar de o árbitro não executar atividade de poder estatal, a lei processual colocou juiz e árbitro lado a lado, posto que, na prática, ambos se revezam em busca de alcançar o mesmo propósito, qual seja, apresentar uma solução ao conflito de interesses submetido à análise da figura de um terceiro teoricamente imparcial. 


\section{Conclusão}

Do exposto, depreende-se o progresso obtido a partir da transmutação do Estado tipicamente liberal para o Estado Constitucional, representado pela sustentação de direitos fundamentais. Dessa noção contemporânea, extrai-se nova formatação social, na medida em que as desigualdades são percebidas pela própria sociedade, constituindo elemento imprescindível à reorientação da própria noção de legalidade, que não mais apenas se ocupa de limitar os poderes estabelecidos, mas afirma o propósito de alcançar sua dimensão mais substancial, delimitando a ingerência estatal na liberdade individual e ampliando-a ao campo omissões institucionais.

Consequência disso, no contexto da jurisdição estatal, o Estado-poder lança mão do Estado-juiz para dar novo sentido e extensão à atividade de aplicação da lei às situações reais da vida, vez que o pronunciamento do julgador passa a representar muito mais do que simplesmente a mera vontade temporalmente estática do legislador por ocasião da tarefa legiferante. O juiz, então, interpreta o direito posto e confere um caráter mais dinâmico e abrangente às normas sociais, ao mesmo tempo em que o próprio Estado também estende o campo de liberdade à sociedade, conferindo maior espaço de ação para os cidadãos, particularmente no que diz respeito ao direito de cada membro do agrupamento social recorrer aos órgãos estatais com o objetivo de resolver seus conflitos de interesses.

Nessa correspondência entre realidade social e ampliação e constitucionalização do direito, um aspecto que ganha intenso relevo é o acesso à justiça, atualmente consubstanciado na garantia da inafastabilidade da jurisdição, não podendo o ente estatal deixar de apreciar qualquer lesão ou ameaça a direito levada ao seu conhecimento, no intuito de se obter do Poder Público uma reposta juridicamente adequada e efetiva. Dessa forma, parte-se da visão tradicional do Poder Judiciário enquanto mecanismo oficial de resolução de controvérsias sociais, tendo em vista sua função preponderantemente desenvolvida no sentido de relevar o direito vigente ante as demandas sociais suscitadas a partir dos acontecimentos usuais do chamado mundo fenomênico.

Nessa toada, apresenta-se o Poder Judiciário como o mecanismo estruturalmente capaz de substituir, com oficiosidade, a vontade das partes litigantes, de modo a percebê-lo, pelo menos a princípio, como a alternativa mais acreditável quando se trata de pacificação social, particularmente pela sua força impositiva, representada pelo caráter definitivo ostentado pela decisão judicial regularmente transitada em julgado. Todavia, ante a recorrente morosidade do serviço estatal e não rara insatisfação social com determinadas resoluções judiciais, em bom tempo o próprio Estado, por meio de seu regramento processual, confere aos pretensos jurisdicionados a possibilidade de buscarem a solução de suas próprias contendas, fundamentados na autonomia da vontade.

Apercebe-se, com isso, o importante papel dos mecanismos consensuais de solução de conflitos, tais como a conciliação e a mediação, quer na esfera judicial ou extrajudicial. A par disso, a justiça arbitral também se revela um avanço no que toca à expectativa de efetiva resolução de litígios, uma vez que, nesse meio, também vigora a vontade das partes por ocasião da submissão do conflito ao crivo arbitral, a despeito de também se vincularem ao produto da decisão proferida pelo árbitro. De todo modo, conciliação, mediação e arbitragem são indícios constatados da abertura jurisdicional do Estado contemporâneo, que, ao constitucionalizar direitos, também amplia as possibilidades de pacificação social, não se restringindo a uma visão antiquada de conferir credibilidade de decisão tão somente às decisões puramente judiciárias.

Daí, vê-se o porquê da nítida intenção de ampliar o direito constitucional de acesso à justiça e, em especial, aos mecanismos de resolução de contendas sociais já na fase inicial da apreciação dos casos concretos, não apenas como resposta oficial do Estado-juiz, na atividade estritamente jurisdicional, mas, acima de tudo, por meio do diálogo entre sujeitos detentores de pretensões inicial e essencialmente díspares, de modo a harmonizar os interesses postos em questão para fins de pacificação gradativa dos atritos comumente encontrados no seio dos grupos sociais, agilizando, inclusive, as condições de evolução do arranjo comunitário por meio da alternativa legal e constitucionalmente garantida de se buscar a autogestão dos 
conflitos.

Por fim, para trabalhos científicos futuros, sugere-se a incursão na essência processual de cada método de resolução consensual de conflitos, relacionando-os com a ideia imperante de jurisdição no contexto do Estado Constitucional de Direito, de modo a enfatizar a consensualidade presente na gestão dos conflitos como uma forte tendência do direito contemporâneo, amparado na missão de salvaguarda de direitos e garantias fundamentais, a fim de destacar a importância da vontade das partes como elemento indispensável no momento de se formular uma solução para a contenda social, aproximando-se dos reais interesses das partes envolvidas na controvérsia em questão.

\section{Referências}

Alvim, E. A., Granado, D. W. \& Ferreira, E. A. (2019). Direito processual civil. Saraiva Educação.

Ávila, E. M. (2012). Mediação judicial e extrajudicial: aspectos sociais e jurídicos. Revista dos Tribunais, 916, $189-204$.

Awad, D. R. (2018). Mediação após o novo código de processo civil e a lei de mediação: avanço ou retrocesso? Revista de Arbitragem e Mediação, 57, 355372 .

Azeredo, C. M. de O. \& Moura, C. da S. (2018). Mediação no novo CPC: avanços e desafios. Revista de Arbitragem e Mediação, $51,461-478$.

Basílio, A. T. P. (2003). Mediação: relevante instrumento de pacificação social. Revista dos Tribunais, 20, $309-324$.

Brasil. (1988). Constituição da República Federativa do Brasil. http://www.planalto.gov.br/ccivil_03/constituicao/constituicao.htm

Brasil. (2010). Resolução no 125, de 29 de novembro de 2010, do Conselho Nacional de Justiça (CNJ). Dispõe sobre a Política Judiciária Nacional de tratamento adequado dos conflitos de interesses no âmbito do Poder Judiciário e dá outras providências. https://atos.cnj.jus.br/atos/detalhar/156

Brasil. (2015). Lei $\mathrm{n}^{\mathrm{o}}$ 13.105, de 15 de março de 2015. Institui o Código de Processo Civil. http://www.planalto.gov.br/ccivil_03/_ato20152018/2015/lei/113105.htm

Brasil. (2010). Código de ética de conciliadores e mediadores judiciais. https://www.cnj.jus.br/wp-content/uploads/2014/04/resolucao_125_291 12010_23042014190818.pdf

Brasil. (2015). Lei no 13.140, de 26 de junho de 2015. Institui a Lei da Mediação http://www.planalto.gov.br/ccivil_03/_ato2015-2018/2015/lei/113140.htm

Cervo, A. L. (2007). Metodologia científica. Pearson Prentice Hall.

Cintra, N. L. (2016). Mediação privada: aspectos relevantes da Lei 13.140/2015. Revista dos Tribunais, 967, 68-85.

Filho, M. M. (2018). Direito processual civil. Atlas.

Folger, J. P., Neto, A. B. \& Barros, J. (2016). Mediação transformativa: preservando o valor único da mediação em contextos de disputa. Revista dos Tribunais, 51, 439-459.

Fuoco, P. F. (2015). O papel estratégico do advogado na mediação no contexto empresarial. Revista dos Tribunais, 47, $277-296$.

Gil, A. C. (2002). Como elaborar projetos de pesquisa. Atlas.

Marinoni, L., Arenhart, S. C. \& Mitidiero, D. (2017). Novo código de processo civil comentado. Revista dos Tribunais.

Martins, C. B. V. da C., Valdetaro, L. G. \& Simões, A. P. (2019). O papel do advogado na mediação. Revista de Arbitragem e Mediação, 60, 63-88.

Medina, J. M. G. (2020). Curso de direito processual civil moderno. Thomson Reuters Brasil.

Mendes, B. C. A. (2016). A jurisdição no estado constitucional. Revista DIREITO E JUSTIÇA: Reflexões sóciojurídicas, 26, 152-169.

Monnerat, F. (2020). Introdução ao estudo do direito processual civil. Saraiva Educação.

Pinho, H. D. B. de. (2020). Manual de direito processual civil contemporâneo. Saraiva Educação.

Pinho, H. D. B. de. (2015). O histórico da lei de mediação brasileira: do projeto de lei 94 à lei 13.140/2015. Revista de Arbitragem e Mediação, 46, 123-139.

Padilha, R. (2020). Direito constitucional. Método.

Rius, C. E. (2020). A mediação no direito positivo brasileiro. Revista dos Tribunais, 1018, 21-40.

Rodrigues, D. C. (2018). Mediação obrigatória no processo civil: reflexões à luz do direito comparado, do CPC/2015 e da lei de mediação (Lei 13.140/2015). Revista de processo, 285, 365-396.

Tartuce, F. (2019). Mediação nos conflitos civis. Método.

Tartuce, F. (2016). O novo marco legal da mediação no direito brasileiro. Revista dos Tribunais, 258, 495-516. 